\title{
EFFECTS OF DIETARY LEVELS OF ENZYME (MAXIGRAIN®) SUPPLEMENTED YAM PEEL MEAL ON PERFORMANCE AND CARCASS CHARACTERISTICS OF WEANER RABBITS
}

\author{
B. YAKUBU, T. F. MBAHI, M. I. BAKO AND M. ANTYEV \\ (Received 13 July 2016; Revision Accepted 8 August 2016)
}

\begin{abstract}
A study was carried out to determine the effects of dietary levels of enzyme supplemented yam peel meal (YPM) on performance and carcass characteristics of weaner rabbits. Five diets were formulated using YPM to replace maize at $0 \%, 25 \%, 50 \%, 75 \%$ and $100 \%$ representing diets $1,2,3,4$ and 5 respectively. All the diets were supplemented with Mixagrain ${ }^{\circledR}$ enzyme at $200 \mathrm{~g}$ except the control diet $1(0 \%)$. Thirty weaner rabbits consisting of mixed breeds and sexes were randomly allotted to the five dietary treatments with six rabbits per treatment and replicated 3 times with 2 rabbits per replicate in a completely randomized design. On the $56^{\text {th }}$ day of the experiment, 3 rabbits from each treatment were randomly selected for carcass and internal organs evaluation. Result of performance shows no significant differences $(P>0.05)$ across the treatments for all the parameters measured for growth performance. Feed cost $/ \mathrm{kg}$ (gain) reduces from $\$ 225.68$ in diet $1-\$ 189.15$ in diet $5(100 \%)$ while cost savings increased from 0.9 in diet 1 - 28.33 in diet $5(100 \%)$. Result of carcass and internal organs characteristics did not show any significant differences $(P>0.05)$ except for small and large intestine length in diets $4(75 \%)$ and diet $5(100 \%)$. Based on this result therefore, enzyme supplemented YPM can be used to replace maize completely.
\end{abstract}

KEYWORDS: Enzymes, yam peel meal, performance, carcass, weaner rabbits

\section{INTRODUCTION}

In developing countries including Nigeria, the inadequacy of animal protein intake is well spread and this has greatly affected the living standard of the people. It is evident that there is shortfall in the supply of meat in the country to meet the demand of the ever increasing growing population (FAO, 2001). Rabbits have several characteristics that if properly harnessed can be used to bridge the gap in protein intake. The small body size, short generation interval, rapid growth rate, genetic diversity and high reproductive potentials are characteristics which make rabbit suitable as meat producing mini-livestock in developing countries (Aduku and Olukosi, 1990; Lebas et al., 1997; Omole et al, 2007).

Conventional feed ingredients that are used in formulating feeds for domestic animals are very scarce and are costly since humans and other monogastric animals like pigs and poultry also compete for the ingredients. This has resulted into escalating cost of production which makes animal protein not affordable to most Nigerians. Most green forages used in rabbit feeding is available only during the rainy season and as such cannot sustain rabbit production throughout the year. Therefore, to arrest the escalating feed cost, there is the need for the integration of some non- conventional feed sources which has no direct human feed value into livestock production (Adeola and Olukosi, 2008). One of such potential alternatives is yam peel meal (YPM) which is cheaply available in Nigeria (Aguihe et al., 2015) and can serve as a cheaper energy source in rabbits (Olumo, 2011). Nigeria produces more than 37 miillion tons of yam representing $71 \%$ of world yam production. Yam peel consists of $11 \%$ crude protein with metabolizable energy of $2604 \mathrm{kcal} / \mathrm{kg}$ (Eka, 1998; ljaiya et al., 2005). YPM has high dietary fibre in form of soluble non-starch polysaccharides which limit its use in monogastric animals (Ezieshi and Olumo, 2011). Supplementation of fibrous diets with exogenous enzymes has been shown to improve performance, enhance production efficiency and increase the effectiveness of nutrient utilization ( Aguihe et. al., (2015).

The study therefore was carried out to evaluate the effect of Maxigrain $®$ enzyme supplementation on performance and carcass characteristics of weaner rabbits.

\section{MATREIALS AND METHODS}

\section{Experimental site}

This study was conducted at the Rabbitry Unit of Gombe State Ministry of Agriculture and is located within Gombe metropolis. Gombe lies between Latitude $10.29^{\circ}$ North and Longitude $11.17^{\circ}$ East with an altitude of

B. Yakubu, Department of Animal Science and Range Management, Modibbo Adama University of Technology, Yola, Nigeria

T. F. Mbahi, Department of Animal Science and Range Management, Modibbo Adama University of Technology, Yola, Nigeria

M. I. Bako, Department of Animal Science and Range Management, Modibbo Adama University of Technology, Yola, Nigeria

M. Antyev, Department Animal production Technology, College of Agriculture, Jalingo, Taraba State Nigeria 
$449 \mathrm{~m}$ above sea level. The mean maximum and minimum temperatures are $32.80^{\circ} \mathrm{C}$ and $18.30^{\circ} \mathrm{C}$ respectively. Gombe metropolis has a rainfall distribution range from $970.7 \mathrm{~mm}-1142 \mathrm{~mm}$ annually, with a mean of $1009.4 \mathrm{~mm}$. The vegetation of the area is savannah grass land (Gombe State Government, Diary 2009).

\section{Source and processing of experimental materials}

The yam peels were collected from restaurants and several household kitchens within Gombe metropolis. The yam peels were sorted out to remove dirt's and other unwanted substances in the peels. Then it was sun dried on a concrete floor for five days. When properly dried it was then milled in to fine particles of $2 \mathrm{~mm}$ in diameter using a hammer mill and used to formulate the experimental diets. Maxagrain ${ }^{\circledR}$ enzyme manufactured by Petrus pharmaaceutical pune, India and Market by Polchem group Nigeria was purchased and used for the study.

\section{Experimental rabbits and management}

Thirty weaner rabbits aged 6-8 weeks were used for the experiment. The rabbits were sourced from the National Veterinary Research Institute (N.V.R.I.) VOM,
Jos, Plateau State, Nigeria. After arrival of the rabbits, they were allowed to acclimatize to the new environment for a week before the experiment begins. During the period they were given anti-stress (vitalite ${ }^{\circledR}$ ) and were feed with hay and maize offal. They were also dewormed using Piperazine ${ }^{\circledR}$ against intestinal parasites. The rabbits were housed in individual cages with feeders and drinkers provided in each cage. All management practices as recommended by Aduku (1990) were observed.

\section{Experimental diets and design}

Five experimental diets were formulated and evaluated during the 56days: Diet 1 was the control diet without YPM; diet 2 contains 25\% YPM, diet 3, 50\% YPM, diet 4, 75\% YPM while diet 5 was $100 \%$ YPM. Maxigrain $\circledast$ enzyme was supplemented at $200 \mathrm{~g}$ in all the diets except the control. The ingredients composition of the experimental diets is shown in Table 1. Thirty (30) weaner rabbits were randomly assigned to the five dietary treatments consisting of six (6) rabbits per treatment and replicated three times with two (2) rabbits per replicate in a completely randomized design.

Table1: Percentage composition of experimental diets.

\begin{tabular}{llllll}
\hline Ingredients (\%) & $\begin{array}{l}\text { Diet 1 } \\
(0 \%)\end{array}$ & $\begin{array}{l}\text { Diet 2 } \\
(25 \%)\end{array}$ & $\begin{array}{l}\text { Diet 2 } \\
(50 \%)\end{array}$ & $\begin{array}{l}\text { Diet 4 } \\
(75 \%)\end{array}$ & $\begin{array}{l}\text { Diet 5 } \\
(100 \%)\end{array}$ \\
\hline Maize & 39.20 & 33.30 & 19.5 & 5.70 & 0.00 \\
Yam peel meal & 0.00 & 5.70 & 19.5 & 33.30 & 39.00 \\
Groundnut cake & 17.50 & 17.50 & 17.50 & 17.50 & 17.50 \\
Wheat Offal & 40.00 & 40.00 & 40.00 & 40.00 & 40.00 \\
Bone Meal & 2.50 & 2.50 & 2.50 & 2.50 & 2.50 \\
Salt & 0.25 & 0.25 & 0.25 & 0.25 & 0.25 \\
Vitamin premix & 0.25 & 0.25 & 0.25 & 0.25 & 0.25 \\
Lysine & 0.10 & 0.10 & 0.10 & 0.10 & 0.10 \\
Methionine & 0.20 & 0.20 & 0.20 & 0.20 & 0.20 \\
Enzyme & 0.00 & 0.20 & 0.20 & 0.20 & 0.20 \\
Total & 100 & 100 & 100 & 100 & 100 \\
Determined Analysis & & & & & \\
Crude protein & 18.06 & 18.25 & 18.29 & 18.32 & 18.69 \\
Ether extract & 5.48 & 5.81 & 5.60 & 5.77 & 5.87 \\
Crude fibre & 11.48 & 12.36 & 12.56 & 12.61 & 12.89 \\
Nitrogen free extract & 58.82 & 58.33 & 59.27 & 58.03 & 57.52 \\
Ash & 6.54 & 6.67 & 7.71 & 8.64 & 8.94 \\
ME (kcal/kg) & 3201.87 & 3198 & 3164.68 & 3123.99 & 3120.60
\end{tabular}

+ Vitamin premix provides per Kg; Vitamin A, 8000, IU; vitamin D3, 1600 IU; Vitamin 51 IU; Vitamin K3, 2 mg; Thiamine B1 1.5mg; Niacin, 15mg; Pantothenic acid, 0.5mg; Vitamin B2, 4mg;Vitamin B12, $0.01 \mathrm{mg}$; Folic acid;5mg; Vitamin B6, 1.5mg; Biotin, 0.02mg;Antioxidant,0. 125mg; Zn0.095; Fe 0.02g; Cu 0.005g; I 0.0012g; Se 0.2g; Co 0.2g. ++Maxagrain $®$ enzyme produced by Petrus pharmaceutical Pune, India and marketed by Polchem group Nig.

\section{Data collection}

Body weight was taken weekly while feed intake was recorded daily for a period of 56 days. Body weight gain was obtained by subtracting initial body weight gain from final weight of the rabbits and the FCR was calculated by dividing feed intake by body weight gain. Feed cost $/ \mathrm{kg}$ was calculated from current market prices of feed ingredients as of the time of the study.

\section{Carcass and internal organs measurement}

At the end of week eight, three (3) rabbits were randomly selected from each treatment and fasted for $12 \mathrm{hrs}$ but water was provided ad libitum. Thereafter the rabbits were weighed, slaughtered, flayed (skinned) and eviscerated to obtain the carcass weight. The pelt (skin) and all the internal organs were weighed separately. The dressing percentages were calculated as described by Olumo (2011)

$$
\text { Dressing percentage }=\frac{\text { Carcass weight }}{\text { Live weight }} \times 100
$$

\section{Chemical analysis}

Proximate analysis of YPM and the five experimental diets were carried out to determine their 
proximate components using the analytical methods described by AOAC, (2006).

\section{Statistical analysis}

All the data obtained during the experiment were subjected to one way analysis of variance (ANOVA) as described by Steel and Torrie (1980), and means were separated using Duncan Multiple Range Test (Duncan, 1955).

\section{RESULTS AND DISCUSSION}

\section{Proximate composition of yam peel meal (YPM)}

The proximate composition of YPM is presented in Table 2. The result of the analysis showed that YPM contained $92.86 \%$ DM, $10.695 \mathrm{CP}, 2.85 \% \mathrm{EE}, 8.5 \% \mathrm{CF}$, $4.61 \%$ Ash and $73.35 \%$ NFE. The CP content of $10.69 \%$ observed in this study was similar to the values of $10.52 \%$ reported by Aguihe et al., (2015) but lower than $12.10 \%$ reported by Yakubu et al., (2013). The ether extract (EE) was above the reported value of $1.30 \%$
(Akinmutimi et al,, 2006) and 0.95\% (Ekenyem; 2006). The crude fiber (CF) which is the amount of indigestible carbohydrates present in the feed sample was lower than the values of 9.47 reported by Aduku (1990) but higher than $7.20 \%$ reported by Akinmutimi and Anakebe, (2008), 7.78\% (Uchewa et al., 2014). and 6.30\% (Ekpo et al., 2015). The nitrogen free extract (NFE) value observed in this study indicates that YPM can be used as a good source of energy in rabbit production.

The variation observed in the proximate composition of YPM when compared with other workers could be due to differences in specie of the yam (Akinmutimi et al., 2006), agronomical practices such as fertilizer application, soil type, and rainfall as reported by Uchewa (2014). The metabolizable energy which was calculated using the formula described by Pauzenga (1985) as: $\mathrm{ME}(\mathrm{kcal} / \mathrm{kg})=37 \times \% \mathrm{CP}+81.1 \times \% \mathrm{EE}+$ $35.5 \times \%$ NFE was $3230 \mathrm{kcal} / \mathrm{kg}$ and was higher than the values reported by Ezieshi and Olumo, (20011) and Aguihe et al., (2015).

Table 2: Proximate composition of yam peel meal (YPM).

\begin{tabular}{lc}
\hline Parameters & Percentage \\
\hline Dry matter & 92.86 \\
Crude protein & 10.69 \\
Ether extract & 2.85 \\
Crude fibre & 8.50 \\
Ash & 4.61 \\
Nitrogen free extract & 73.35 \\
Metabolizable energy $(\mathrm{Kcal} / \mathrm{Kg})$ & 3230 \\
\hline
\end{tabular}

\section{Performance characteristics}

Table 3 shows the performance of weaner rabbits fed diets containing different levels of YPM

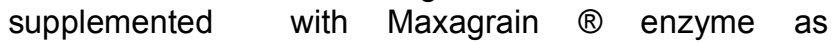
replacement for maize. There was no significant difference $(P<0.05)$ across the treatments for parameters measured for growth performance. The final weight ranged from $1641.67 \mathrm{~g}-1800 \mathrm{~g}$. This was higher than the range of $850 \mathrm{~g}-1450 \mathrm{~g}$ reported by Abdu et al., (2011) and 1271.24-1432.96g reported by Yakubu et al., (2013). The observed differences could be as a result of enzyme supplementation of the yam peels as reported by Biswas et al., (1999); Swain and Johri, (1999); Midau et al., (2011). It has been reported that enzymes supplementation resulted in improved feed utilization efficiency (Penge et al., 2003) and reduce viscosity of ingesta in the intestine and showed a marked improvement on the various morphological effects of feeding fibrous materials to monogastrics (Adeyemi et al., (2013). It was however lower than $2.06 \mathrm{~kg}-2.34 \mathrm{~kg}$ reported by Ukachukwu et al., (2011) on graded dietary levels of composite cassava meal.

The average daily feed intake showed no significant difference $(P>0.05)$ between treatments but the rabbits tend to eat less as the level of YPM inclusion increases. The range for feed intake observed in this study was $62.47 \mathrm{~g}-65.67 \mathrm{~g}$. Diverse reports exist on the relationship between exogenous enzyme supplementation and feed intake. Adizal and Ohtani, (2002); and Rahman et al., (2005) reported that enzymes have no effect on feed intake while Kadam et al. (1991) reported reduction in feed intake as a result of enzyme supplementation. Similarly, average daily weight gain and feed conversion ration were similar $(P>0.05$ across all the treatments. Rabbits on diet 5 (100\% YPM) however had a higher ADWG (16.10g) on numerical basis. This agrees with the reports of Classen et al. (1995) and Scott et al. (1998). Feed conversion ratio (FCR) also showed no significant difference $(P>0.05)$ between the treatments but rabbits on diet 5 $(100 \%$ YPM) had a superior FCR of (3.93) when compared to other treatments.

Feed cost decreased as the level of inclusion of YPM increases. Several studies have shown that increasing the inclusion levels of YPM led to reduction in feed cost (Agunbiade et al., 2002, Ekenyen et al., 2006; Ajayi et al., 2007). Rabbits on diet 1(0\% YPM) had the highest feed cost ( $\$ 5.63 / \mathrm{kg}$ ) while rabbits on diet 1 (100\% YPM) had the least feed cost ( $\$ 48.78 / \mathrm{kg})$. This was similar to the values obtained by Yakubu et al. (2013); Ayoola and Akinban (2011) and Ademola et al. (2012) who observed lower fed cost/kg gain when dietary fibre sources were supplemented with Mixagrain ${ }^{\circledR}$ enzymes. The result shows that $100 \%$ enzyme supplemented YPM was more economical for feeding rabbits than using maize. This is because YPM are cheaper and less competitive when compared to maize (Ukachukwu, 1997). The value for the feed cost saving increased from $\$ 0.9$ - $\$ 28: 00$ as the level of enzyme supplemented yam peel meal increased. 
Table 3: Performance and exosmic characteristics of weaner rabbits fed enzyme supplemented yam peel meal

\begin{tabular}{lllllll}
\hline Parameters & $\begin{array}{l}\text { Diet 1 } \\
(0 \%)\end{array}$ & $\begin{array}{l}\text { Diet 2 } \\
(25 \%)\end{array}$ & $\begin{array}{l}\text { Diet 3 } \\
(50 \%)\end{array}$ & $\begin{array}{l}\text { Diet 4 } \\
(75 \%)\end{array}$ & $\begin{array}{l}\text { Diet 5 } \\
100 \%\end{array}$ & SEM \\
\hline Initial weight (g) & 825.00 & 841.67 & 900.00 & 866.67 & 900.00 & $62.47^{\text {ns }}$ \\
Final weight (g) & 1700.00 & 1641.67 & 1683.33 & 1691.67 & $\begin{array}{l}1800.00 \\
79.58^{\text {ns }}\end{array}$ \\
Average daily feed intake (g) & 63.00 & 65.67 & 64.93 & 63.77 & 62.47 & $1.38^{\text {ns }}$ \\
Average daily weight gain (g) & 15.63 & 14.30 & 13.90 & 14.70 & 16.10 & $1.08^{\text {ns }}$ \\
Feed conversion ratio & 4.10 & 4.97 & 4.77 & 4.37 & 3.93 & $0.38^{\text {ns }}$ \\
Feed cost NN/kg & 55.63 & 54.39 & 51.92 & 49.91 & 48.78 & - \\
Cost of total feed intake (\#/kg) & 198.57 & 197.61 & 188.48 & 176.39 & 170.24 & - \\
Feed cost/kg (\#/gain) & 225.68 & 266.14 & 241.62 & 212.52 & 189.15 & - \\
Cost savings & - & 0.96 & 10.09 & 22.18 & 28.33 & - \\
\hline
\end{tabular}

\section{Carcass and internal organs characteristics}

The effect of enzyme supplementation of YPM on carcass and internal organs characteristics of weaner rabbits is shown in Table 4 . Results revealed that there was no significant variation $(P>0.05)$ in all the parameters measured. This was similar to the results obtained by Sagheer and Hassanein (2014) who recorded no significant effect in carcass criteria in their study due to enzyme supplementation in the diets of rabbits, except in the weight of the liver. The dressed weight $(836.67 \mathrm{~g})$ and dressing percentage (51.50\%) were higher in rabbits on diet $5(100 \%)$.

The result indicates that the diet had no adverse effect on the carcass traits of rabbits. The increase in dressing percentage recorded in this study with enzyme supplemented YPM agrees with the report of Lesson et al. (1996). Similarly Abbas et al. (1998) reported that enzyme supplementation of fibrous diet improved the growth rate, thereby increasing the dressing percent. Bharathidhasan et al. (2009) also reported an increased dressing percent and carcass yield in birds fed enzyme supplemented diets.

The internal organs measurements were also similar across the treatments accept for small and large intestine lengths. There was a progressive increase in length of small and large intestines from $59.00-92.67 \mathrm{~cm}$ and $17.33-24.67 \mathrm{~cm}$ respectively as the levels of enzyme supplemented YPM increase. This could be as a result of high fibre content of YPM. Results also showed that internal organs that are involved in detoxification were not affected by replacement levels of YPM indicating that the ingredient is safe for rabbit feeding. It has been reported that, if there is any major effect of antinutritional factors, organs like kidney and liver would be affected since they are the major detoxification organs (Uchewa, 2014).

Table 4: Carcass yields of rabbits feed enzyme supplemented yam peal meals

\begin{tabular}{|c|c|c|c|c|c|c|}
\hline Parameters & $\begin{array}{l}\text { Diet } 1 \\
(0 \%)\end{array}$ & $\begin{array}{l}\text { Diet } 2 \\
(25 \%)\end{array}$ & $\begin{array}{l}\text { Diet } 3 \\
50 \%\end{array}$ & $\begin{array}{l}\text { Diet } 4 \\
(75 \%)\end{array}$ & $\begin{array}{l}\text { Diet } 5 \\
(100 \%)\end{array}$ & SEM \\
\hline Live weight (g) & 1526.67 & 1540.00 & 1480.00 & 1556.67 & 1603.3 & $107.55^{\text {ns }}$ \\
\hline skin weight (g) & 126.67 & 132.33 & 136.67 & 113.33 & 150.00 & $13.98^{\mathrm{ns}}$ \\
\hline Dressed weight (g) & 780.00 & 780.00 & 763.33 & 766.67 & 826.67 & $5.38^{\mathrm{ns}}$ \\
\hline $\begin{array}{l}\text { Dressing \% } \\
\text { Internal organs }\end{array}$ & 51.26 & 50.37 & 51.28 & 49.11 & 51.50 & $2.28^{\mathrm{ns}}$ \\
\hline Lungs weight (g) & 8.40 & 8.53 & 12.60 & 9.33 & 10.13 & $1.50^{\mathrm{ns}}$ \\
\hline Heart weight $(\mathrm{g})$ & 3.70 & 3.23 & 3.17 & 3.57 & 3.63 & $1.03^{\mathrm{ns}}$ \\
\hline Liver weight (g) & 50.80 & 37.97 & 35.97 & 42.20 & 38.47 & $3.29^{\mathrm{ns}}$ \\
\hline Kidney weight (g) & 9.13 & 10.23 & 9.67 & 10.60 & 12.87 & $0.89^{\mathrm{ns}}$ \\
\hline Stomach weight $(\mathrm{g})$ & 85.43 & 74.33 & 54.67 & 83.70 & 48.80 & $9.87^{\mathrm{ns}}$ \\
\hline Small intestine weight (g) & 119.27 & 107.57 & 110.80 & 99.80 & 103.77 & $11.42^{\text {ns }}$ \\
\hline Large intestine weight (g) & 55.87 & 73.43 & 53.57 & 63.00 & 48.17 & $6.27^{\mathrm{ns}}$ \\
\hline Ceacal weight $(\mathrm{cm})$ & 6.73 & 6.50 & 6.03 & 5.30 & 7.60 & $1.04^{\mathrm{ns}}$ \\
\hline Small intestine length $(\mathrm{cm})$ & $59.00^{c}$ & $63.00^{c}$ & $72.67^{b}$ & $76.33^{b}$ & $92.67^{a}$ & $6.34^{*}$ \\
\hline Large intestine length (cm) & $17.33^{b}$ & $18.33^{a b}$ & $21.33^{\mathrm{ab}}$ & $24.00^{a}$ & $24.67^{a}$ & $1.81^{\star}$ \\
\hline
\end{tabular}
abc; Means on the same row bearing different superscript differ significantly $(P<0.05)$

\section{CONCLUSION}

From the results obtained in this study, it can be concluded that YPM can replace maize completely in the diets of weaner rabbits. The uses of Maxagrain ${ }^{\circledR}$ enzyme also resulted in reduction in cost of feed and therefore recommend $100 \%$ inclusion of enzyme supplemented YPM in weaner rabbit's diet.

\section{REFERENCES}

Abbas, W., Khan, S. H and Sarwar, M., 1998. Sunflower oil meal as a substitute for soybean meal in broiler rations with or without multi-enzyme (Kemzyme). Pakistan Vet. J, 18: $124-129$. 
Adeola, O and Olukosi, O. A., 2008. Opportunities and challenges in the use of alternative feed stuffs in poultry production. Nig. Poultry sci. J. 5(4)147155.

Ademola, S. G., Egbewande, O. O., Lawal, T. E., Isah, A. T and Kuranga, S. M., 2012. Effects of Roxazyme G and Maxigrain on performance of, egg quality, cost benefit and haematological parameters of laying hens fed wheat offal; corn bran and brewery dry grain diets. International journal of Poultry Science, 11(1): 33-38.

Adeyemi, O. A., Jimoh, B and Olufade, O. O., 2013. Soybean meal Replacement with cassava leaf: Blood meal mix with or without Enzyme in Broiler Diets. Archivos de Zooteinia, 62 (238):275 - 285.

Adrizal, A and Ohtani, S., 2002. Effects of vice bran nonstarch polysaccharides and fibre degrading enzymes on performance and nutrient digestibility in broiler chichs. J. Poultry Science, 39: 109 - 107.

Aduku, A. O., 1990. Tropical Feedstuff Analysis Table. Department of Animal Science. Faculty of Agriculture, Ahmadu Bello University, SamaruZaria.

Aduku, A. O and olukosi, J. O., 1990. Rabbits Management in the tropics production, processing, utilization, marketing. Economics practical training, research and future prospect, living book series, G.U. publication, Abuja F.C.T .pp 1-105.

Agunbiade, J. A., Bello, R. A and Adeyemi, O. A., 2002. Performance characteristics of weaner rabbits on cassava peel-based balanced diets. Nig. Journal of Animal Production 32: 67-72

Aguihe, P. C., Kehinde, A. S and lyayi, E. A., 2015. Effects of enzyme (Mixagrain) supplementation on performance characteristics and nutrient digestibility of growing Japanese quails (Cortunix cortunix japonica) fed diets containing yam peel meal. Nig. J. Anim. Sci. 17(1):65-74

Akinmutimi, A. H., Odeomolan, V. U and Obasienkong, S. F., 2006. Effects of replacement maize with ripe plantain and yam peels in diet of weaner rabbits. Journal of Animal and Veterinary Advances. 5(9) $737-740$.

Akinmutumi, A. $\mathrm{H}$ and Anakebe, O. C., 2008. Performance of weaner rabbits fed graded levels of yam and sweet potatoes peel meal in place of maize based diet. Pakistan Journal of nutrition 7 (5): 700-704.

AOAC., 2006. Association of Official Analytical Chemist, Official Methods of Analysis. $15^{\text {th }}$ edition Washinton, D.C. USA.
Ayoola, M. A and Akinban, A. S., 2011. Effects of replacing maize with sundried yam peel meal on growth performance carcass characteristics and economics of production of meat type rabbit. Researcher. 2(4); 70-73

Bharathidhassan, A., Chandrasekaran, D., Natarajan, A., Ravi, R and Ezhilvalavan, S., 2009. Effect of enzyme supplementation on carcass quality, intestinal viscosity diet. Tamilnadu J. Vet. Anim. Sci, 5: 239-245.

Biswas, J., Mandal, L and Sarker, S. K., 1999. Studies of enzymes supplementation and herbal preparation at different levels of energy on the performance of broilers. J. Interacademic, 3: 5358.

Duncan, D. B., 1955. Multiple Range Tests and Multiple F. Tests. Biometrics. 11K1-42

Eka, O. U., 1998. Roots and tubers in: Nutritional quality of plant foods. Macmillan press, London pp. 131.

Ekenyen, B. U., Madubuike, F. N and Dike, O. F., 2006. Effects of partial replacement of (yam peel meal Dioscorea spp) for maize meal (Zea mays) on performance and carcass characteristics of finisher broilers. International Journal of Poultry Science. 5 (10):942-945.

Ekpo, J., Etim, N. N., Eyo, G. D., Offiong, E. E. A and Udo, M. D., 2015. Performance and haematological profiles of crossbred male rabbits fed yam and cassava bye products in the humid tropics. America Journal of Experimental Agriculture 8 (2):93-98.

Ezieshi, E. V and Olumo J. M., 2011. Biochemical evaluations of yam peel meal for broiler chickens. Journal of Agriculture and Social Research. 11(1): 36-48.

FAO., 2001. Food and Agriculture Organization. Food Production Year. 50:160-168

Gombe State Diary., 2009. Gombe state Ministry of Information Publications.

ljaiya, A. T and Awonusi, E. A., 2005. Effects of replacing maize with yam peel meal on the growth performance of weaner rabbits. Journal of Sustainable Tropical Agricultural Research. 91-93.

Kadam, A. S., Ranade, A. S., Rajmane, B. V., Dange, S. $H$ and Pafil, S. S., 1991. Effect of Ezyme supplementation on the performance of broilers: Poultry Advisor, 24: 21 -24.

Lesson, S., Caston, L. J and Yublut, D., 1996. Adding roxazyme to wheat diets of chickens and turkey broilers. J. Appl. Poultry Res, 5: 167 - 172. 
Lebas, F. P., Coudert, H. de Rochanbeau and Theboult,

R. G., 1997. The Rabbit. Husbandry health and Production (New revised editon). Food and Agriculture organization of the United Nations. Rome.

Midau, A., Augutine, C., Yakubu, B., Yahaya, S. M., Kibon, A and Udoyong, A. O., 2011. Performance of broiler chicken fed enzyme supplemented cassava peel meal based diets. Int. J. of Sustain Agric., 3: 1 - 4 .

Olumo, J. M., 2011. Monogastric Animal Nutrition. Principles and practice $2^{\text {nd }}$ Edition St. Jackson Publishing. Benin City Nigeria. pp447

Omole, A., Ajasin, F. O., Olukokun, J. A and Tamiya, A. K., 2007. Rabbit farming without tears. Back yo Agric. Series (7) Green choice Agric Publ. Ibadan

Pauzenga, U., 1985. Feeding parent stock. Zootech characteristics of weaning rabbits fed graded level. International Journal of Agriculture. 34:2225.

Peng, Y. L., Guo, Y. M and Yuan, J. M., 2003. Effect of microbial phytase and xylanase on the growth performance and nutrients digestibility of broilers wet based diets. Asian Aust, J. Animal Sci., 16(2): 239-247.

Sagheer, M and Hassanein, H. H. M., 2004. Effect of enzymes to the diet of Growing Female Rabbits on performance and carcass criteria. Egyptian Poultry Science J. Vol. (34)(1): 259 - 272.

Scott, T. A., Silversides, F. G., Classen, H. L., Swift, M. $\mathrm{L}$ and Bedford, M. R., 1998. Effect of cultivar and environment on the value of western Canadian wheat and barley samples with or without enzyme supplementation. Canadian J. Animal. Sci. 78: 649 - 656 .
Steel and Torrie., 1980. Principle and procedure of statistics. A biometric approach and edition. Mcgrow Hill Book. Co.

Uchewa, E. N., Orogwu, C. E and Nwakpu, P. E., 2014. Effect of yam peel meal (YPM) replacement of maize on the growth performance and carcass traits of weaner rabbits. International Journal of Agriculture Innovations and Research 2(4)2319-1473.

Ukachukwu, S. N., 1997. Alternative feed stuffs and least cost rations for monogastric animals in Nigeria. Journal of Cooperative and Rural Development 5: 14-17

Ukachukwu, S. N., Ekwe, C. C and Ojeola, G. S., 2011. Performance of weaned rabbits fed dietary levels of composite cassava meal. Nigerian Journal of Tropical Science. 13:147-153.

Yakubu, B., Yusuf, H. B and Pwadadi, G., 2013. Response of growing rabbits to diets containing varying levels of yam peel meal as replacement for maize. Taraba Journal of Agricultural Research. Vol. 1 (1) pp. 49-53. 